converting enzyme inhibitors to cause cough: the development of cough and the change in the sensitivity of the cough reflex in the three patients occurred with both enalapril and ramipril. Further studies on the sensitivity of the cough reflex in patients taking different angiotensin converting enzyme inhibitors are required. Pharmacokinetic factors and access of the drugs to tissue sites may be important in the development of cough, but, as shown here, the plasma angiotensin converting enzyme activity is not related to blood pressure or the occurrence of cough. In some patients a reduction in the dose of the inhibitor may alleviate the cough (personal observation), but there is no direct evidence of dose dependence of the symptom.

Cough caused by treatment with angiotensin converting enzyme inhibitors will be increasingly important as these drugs are prescribed more widely. Further studies to elucidate the mechanism of this side effect are required and may help to clarify the mechanisms of cough as a symptom of respiratory disease.

This work was supported by grants from the Medical Research Council and Hoechst (UK). We thank Hoechst (UK) for providing the ramipril, enalapril, and placebo capsules; Miss Audrey Douglas for secretarial help; and Drs Neil Pride and Graham Taylor for helpful comments.

1 CONSENSUS Trial Study Group. Effects of enalapril on mortality in severe congestive heart failure. Results of the cooperative north Scandinavian enalapril survival study (CONSENSUS). $N$ Engl F Med 1987;316:1429-35.

2 Sharpe N, Murphy J, Smith H, Hannan S. Treatment of patients with symptomless left ventricular dysfunction after myocardial infarction. Lancet $1988 ; \mathrm{i}: 255-9$.

3 Sesoko S, Kaneko Y. Cough associated with the use of captopril. Arch Intern Med 1985;145: 1524 .

4 Israel-Biet D, Delaisements C, Chretien J. Enalapril-induced cough. Lancet 1986;ii:918.

5 Semple PF, Herd GW. Cough and wheeze caused by inhibitors of angiotensinconverting enzyme. N Engl f Med 1986;314:61.

6 Webb D, Benjamin N, Collier J, Robinson B. Enalapril-induced cough L Lance 1986;ii: 1094 .

7 Coulter DM, Edwards IR. Cough associated with captopril and enalapril. BrMed f 1987;294:1521-3.

8 Strumpe KO, Kolloch R, Overlack A. Captopril and enalapril: evaluation of therapeutic efficacy and safety. Practical Cardiology 1984;10:111-24.

9 Hood S, Nicholls MG, Gilchrist NL. Cough with angiotensin convertingenzyme inhibitors. $N Z$ Med f 1987;100:6-7.
10 Collier JG, Fuller RW Capsacin inhalarion in man and the effects of sodium cromoglycate. Br f Pharmacol 1984;81:113-7.

11 Fuller RW, Choudry NB. Increased cough reflex associated with angiotensin converting enzyme inhibitor cough. Br Med f 1987;295:1025-6.

2 Morice AM, Brown MJ, Lowry R, Higenbottam T. Angiotensin-converting enzyme inhibitors and the cough reflex. Lancet 1987; ;i: 1116-8.

13 Crozier IG, Ikram H, Nicholls MG, Jans S. Acute hemodynamic, hormonal and electrolyte effects of ramipril in severe congestive heart failure. $A m$ Cardiol 1987;59:155-63D.

14 Villamil AS, Cairns V, Witte PU, Bertolasi CA. A double-blind study to compare the efficacy, tolerance and safety of two doses of the angiotensin converting enzyme inhibitor, ramipril with placebo. Am $\mathcal{Y}$ Cardiol 1987 59:110-4D.

15 Friedland J, Silverstein E. A sensitive fluorimeter assay for serum angiotensinconverting enzyme. Am $\mathcal{f}$ Clin Pathol 1976;66:416-24.

16 Hanacek J, Davies A, Widdicombe JG. Influence of lung stretch receptors on the cough reflex in rabbits. Respiration 1984;45:161-8.

17 Widdicombe JG. Receptors in trachea and bronchi of the cat $f$ Physiol (Lond) 1954;123:71-104.

18 Sant'Ambrogio G, Remmers JE, De Groot WJ, Callas CT, Mortola JP. Localisation of rapidly adapting receptors in the trachea and main stem bronchus of the dog. Respir Physiol 1978;33:359-66.

19 Coleridge JCG, Coleridge HM. Afferent vagal c-fibre innervation of the lungs and airways and its functional significance. Rev Physiol Biochem Pharmacol 1984;99:101-10.

20 Sant'Ambrogio G. Afferent pathways for the cough reflex. Bull Eur Physiopathol Respir 1987;23(suppl 10): 19-24S.

21 Wharton J, Gulbenkian S, Mulderry PK, et al. Capsaicin induces a depletion of calcitonin gene-related peptide (CGRP)-immunoreactive nerves in the cardiovar 1986;16:289-309.

22 Coleridge HM, Coleridge JCG, Luck JC. Pulmonary afferent fibres of small diameter stimulated by capsaicin and by hyperinflation of the lungs. $f$ Physiol (Lond) 1965;179:248-62.

23 Szolcsanyi J. A pharmacological approach to elucidation of the role of different nerves and receptor endings in mediation of pain. 7 Physiol (Paris) 1977;73:257-9.

24 Fuller RW, Warren JB, McCusker M, Dollery CT. Effect of enalapril on the skin response to bradykinin in man. Br f Clin Pharmacol 1987;23:88-90.

5 Benjamin N, Cockcroft JR, Collier JG, Dollery CT, Ritter JM, Webh DJ. Local inhibition of converting enzyme and vascular responses to angiotensin and bradykinin in the human forearm. F Physiol (Lond) 1989;412:543-55.

26 Rossoni G, Omini C, Viganot T, Mandelli V, Folco GC, Berti F. Bronchoconstriction by histamine and bradykinin in guinea pigs: relationship to $\mathrm{TXA}_{2}$ generation and the effect of aspirin. Prostaglandins 1980;20:547-57.

27 Nicholls MG, Gilchrist NL. Sulindac and cough induced by" converting enzyme inhibitors. Br Med $\mathcal{F}$ 1987;294:872.

$28 \mathrm{McF}$ adden ER Jr. Exertional dyspnea and cough as preludes to acute attacks of bronchial asthma. N Engl f Med 1975;292:555-9.

29 Bucknall CE, Neilly JB, Carter R, Stevenson RD, Semple PF. Bronchial hyperreactivity in patients who cough after receiving angiotensin converting enzyme inhibitors. BrMed F 1988;296:86-8.

30 Dixon CMS, Fuller RW, Barnes PJ. The effect of angiotensin converting enzyme inhibitor, ramipril on bronchial responses to inhaled histamine and bradykinin in asthmatic subjects. Brf Pharmacol 1987;23:91-3.

31 Berkin KE, Ball SG. Cough and angiotensin converting enzyme inhibition [Editorial]. Br Med f 1988;296:1279.

(Accepted 10 April 1989)

\title{
Accuracy in clinically evaluating pigmented lesions
}

\author{
R K Curley, M G Cook, M E Fallowfield, R A Marsden
}

Departments of

Dermatology and

Histopathology, St

George's Hospital,

London SW17

R K Curley, MD, senior registrar in dermatology M G Cook, MD, consultant histopathologist

M E Fallowfield, MD, senior registrar in histopathology R A Marsden, FRCP, consultant dermatologist

Correspondence to: $\mathrm{Dr}$ Curley.
Abstract

Objective-To determine the ability of three doctors experienced in managing melanocytic lesions to diagnose correctly melanoma, dysplastic naevi, and various benign pigmented lesions.

Design-Independent clinical evaluation and histopathological assessment.

Setting-Pigmented lesion clinic, which patients attend without an appointment for early diagnosis of melanoma.

Patients -86 Patients with lesions that were judged to be benign by at least one of the three doctors.

Interventions-The lesions were excised under local anaesthesia and sent for histopathological examination in coded bottles without clinical details.

Main outcome measure-Comparison of clinical with histopathological diagnosis for each lesion.

Results-A total of 120 lesions were evaluated by at least two of the three doctors. The histopathological diagnoses were made by the same pathologist. The overall sensitivity (diagnostic accuracy) for the three doctors for all types of lesion was $50 \%$. Of the 39 dysplastic naevi, only 19 were identified correctly by all observers, and a further 24 banal lesions were wrongly diagnosed as dysplastic by at least one doctor. Particular difficulty was experienced with small $(<5 \mathrm{~mm})$, flat lesions, which can be banal or potentially malignant.

Conclusions-Critical diagnosis and management decisions concerning pigmented lesions should always be based on a combination of clinical and histopathological assessments and the history of the patient.

\section{Introduction}

The risk of malignant melanoma is increased in people with large numbers of melanocytic naevi ${ }^{12}$ and in those with the dysplastic naevus syndrome. ${ }^{3}$ Previous studies have assumed that benign melanocytic naevi can be distinguished from other banal pigmented lesions such as lentigines and that dysplastic naevi can be recognised on clinical grounds. We tested these assumptions.

\section{Subjects and methods}

We examined 120 pigmented lesions from 86 patients who presented mainly to the pigmented lesion clinic at 
the hospital. The lesions were judged to be benign but were excised for diagnostic purposes or at the patient's request. All of the lesions were evaluated clinically by at least two and often three of us (RAM, MGC, and RKC) independently. (We had all had considerable experience of managing pigmented lesions.) Specimens were sent for histopathological examination in coded bottles without clinical details as the pathologist was also one of the clinical observers, and the results were not available to us until the end of the study, except when necessary for managing the patient. To test the reproducibility of the histopathological diagnosis all of the slides were recoded and resubmitted to the same histopathologist (MGC) for a second evaluation. The criteria for the histopathological diagnoses of the various pigmented lesions were based on the commonly accepted definitions of ephelis; junctional, compound, and intradermal naevi; and seborrhoeic keratoses. $^{4-6}$ An otherwise intradermal naevus was considered to be compound if there were two or more junctional nests in each section examined. As there is some discrepancy regarding the definition of a lentigo we used our own definition, based on that of Pinkus and Mehregan ${ }^{5}$-that is, a lentigo is an area of acanthotic epidermis with an intensely hyperpigmented basal layer, variable elongated rete ridges, and an increased number of basally situated melanocytes, particularly in the rete ridges.

We used the well established histological criteria for diagnosing dysplastic naevi (melanocytic dysplasia). ${ }^{378}$ Essentially these lesions typically have hyperpigmented, elongated rete ridges with fused tips, giving an inverted bridge pattern, and an increased number of melanocytes, which are atypical to various degrees. The atypical melanocytes often form horizontal sheets at the tip of the rete ridges, and in this site they have a spindly configuration. Single, atypical, non-spindly melanocytes are also distributed widely in the basal layer of the epidermis, including the suprapapillary region. The underlying dermis usually shows some sclerosis and infiltration of lymphocytes and often includes the cellular components of a benign naevus.

Although we acknowledge that in routine practice interpretation of histopathological appearances often relies on a clinical history, in this study we were attempting to test our clinical accuracy, and therefore the pathologist's assessment without clinical details was accepted as the final diagnosis.

\section{Results}

In over $80 \%$ of cases (including three of melanoma) the lesions studied were those for which the patient had sought an opinion. Occasionally additional biopsy samples were taken from a patient if multiple naevi were present to try and establish a diagnosis of dysplastic naevi. Each of the three patients with lesions that proved to be melanomas on histopathological examination attended because they thought that the lesion had changed.
All 120 lesions were examined twice by the histopathologist, and in the 11 cases in which there was a discrepancy between the first and second histopathological diagnoses the slides were resubmitted randomly for a third time without his knowledge. In each of these cases the second and third assessments were the same and were taken as the correct diagnosis: in three cases a diagnosis of intradermal naevus was changed to that of compound naevus, and in one case a diagnosis of compound naevus was changed to intradermal naevus (these adjustments were made when it became apparent that a stricter definition of a compound naevus was necessary); five lesions were thought to be dysplastic after further examination; and two lesions that had been categorised previously as dysplastic naevi were later classified as banal.

The final histopathological diagnoses were melanoma (3), dysplastic naevus (39), compound naevus (22), intradermal naevus (30), lentigo (6), seborrhoeic wart (8), and miscellaneous (12). The miscellaneous lesions comprised two actinic keratoses, two dermatofibromas, three blue naevi, one angioma, one angiokeratoma, one clear cell acanthoma, and two complex lesions, which in one case showed features of a seborrhoeic wart and an intradermal naevus and in the other case features of an intradermal naevus and a lentigo.

Overall, only half of the clinical diagnoses were correct, and all three melanomas were misdiagnosed by at least one of us. All three of us saw 14 of the 39 dysplastic naevi and correctly diagnosed five (36\%) of them. The remaining 25 were seen by two of us, and 14 (56\%) were correctly diagnosed by both. A further 24 banal lesions were falsely interpreted as dysplastic by one or more of us.

RAM evaluated 107 lesions and correctly diagnosed 49 , giving a diagnostic accuracy (sensitivity) of $46 \%$; MGC evaluated 59 lesions, of which 31 (53\%) were diagnosed correctly; and RKC evaluated 115 lesions, of which $60(52 \%)$ were diagnosed correctly. The table shows the sensitivity and specificity for diagnosing each type of lesion for each doctor. The specificity refers to the percentage of lesions recognised as not being of a particular type. Thus if out of 100 lesions we saw and identified all of the melanomas and did not diagnose any other lesion as melanoma then the sensitivity and specificity for melanoma was $100 \%$.

\section{Discussion}

Several authors have emphasised the difficulties of clinically diagnosing melanoma. ${ }^{9 \cdot 13}$ In their studies the accuracy of clinically evaluating lesions that proved to be melanomas on histopathological examination ranged from $48 \%$ to $77 \%$, and lesions assessed clinically as melanoma were verified histologically in $43 \%,{ }^{9} 38 \%,{ }^{10}$ and $28 \%{ }^{11}$ of cases. The experience of the doctor also influenced diagnostic accuracy, with dermatologists performing better than other doctors ${ }^{1+16}$ and high rates of accuracy being achieved in some specialist referral centres. ${ }^{17}$

In this study we were concerned with the ability to

Sensitivity and specificity for diagnosing pigmented lesions for each of three doctors (RAM, MGC, and RKC). Figures in parentheses are percentages

\begin{tabular}{|c|c|c|c|c|c|c|}
\hline \multirow[b]{2}{*}{ Type of lesion } & \multicolumn{2}{|c|}{ RAM } & \multicolumn{2}{|c|}{ MGC } & \multicolumn{2}{|c|}{ RKC } \\
\hline & Sensitivity & Specificity & Sensitivity & Specificity & Sensitivity & Specificity \\
\hline Melanoma & $1 / 3$ & $100 / 104(96)$ & $0 / 2$ & $56 / 57(98)$ & $0 / 1$ & $113 / 114(99)$ \\
\hline Dysplastic naevus & $22 / 36(61)$ & $54 / 71(76)$ & $17 / 20(85)$ & $26 / 29(67)$ & $21 / 36(58)$ & $64 / 79(81)$ \\
\hline Compound naevus & $9 / 21 \quad(43)$ & $59 / 86 \quad(69)$ & $0 / 3$ & $52 / 56(93)$ & $7 / 22$ & $81 / 93 \quad(87)$ \\
\hline Intradermal naevus & $2 / 24(8)$ & $83 / 83(100)$ & $7 / 18(39)$ & $39 / 41(95)$ & $16 / 30$ & $72 / 85 \quad(85)$ \\
\hline Lentigo & $3 / 6 \quad(50)$ & $97 / 101(96)$ & $0 / 4$ & $54 / 55(98)$ & $2 / 6 \quad(33)$ & $107 / 109(98)$ \\
\hline Seborrhoeic wart & $5 / 6 \quad(83)$ & $100 / 101(99)$ & $5 / 6(83)$ & $53 / 53(100)$ & $6 / 8 \quad(75)$ & $106 / 107(99)$ \\
\hline Miscellaneous & $7 / 11 \quad(64)$ & & $2 / 6$ & & $8 / 12 \quad(67)$ & \\
\hline Total & $49 / 107(46)$ & & $31 / 59(53)$ & & $60 / 115(52)$ & \\
\hline
\end{tabular}


distinguish between different types of benign pigmented lesion rather than the ability to differentiate benign from malignant lesions. Previous studies of the prevalence of benign and dysplastic melanocytic naevi have assumed that such lesions can be recognised clinically. In Swerdlow's study, however, naevi were diagnosed correctly by doctors in only $61 \%$ of 551 lesions, and of 454 lesions diagnosed histopathologically as naevi, only $74 \%$ were diagnosed correctly by doctors. "In a similar report $80 \%$ of the diagnoses of naevi made by dermatologists proved to be correct on histological examination. ${ }^{18}$ The 74 lesions that were diagnosed clinically as naevi in the study by Ewing and Powell included two malignant melanomas and three basal cell carcinomas. ${ }^{19}$ Grob et al showed that the diagnosis of dysplastic naevi on the basis of clinical criteria alone is also difficult and unreliable. ${ }^{20}$ In the present study we have shown the difficulties of distinguishing between not only dysplastic and banal naevi but also naevi and other pigmented lesions.

As we were assessing the accuracy of our diagnoses, which were based on our own criteria that we use in routine clinical practice, we did not attempt to influence each other or to standardise the criteria. We were, however, aware of the classical features of dysplastic naevi. ${ }^{21-23}$

We experienced difficulties with all types of so called banal lesions - for example, only two of the 30 intradermal and four of the 22 compound naevi were identified correctly by all three of us. We were particularly bad at identifying small, flat lesions and distinguishing between lentigines and naevi: the overall sensitivity for lentigines was only $27 \%$. There were some interesting discrepancies among us in recognising lesions - for example, one of us rarely made a clinical diagnosis of intradermal naevus and tended to interpret all such naevi as compound, whereas another of us interpreted all of the lentigines as naevi. Those lesions that the pathologist found difficult to classify were also more difficult to assess clinically; the overall sensitivity was $36 \%$ (compared with $50 \%$ for all lesions).

After reviewing our results we conclude that clinical distinction between intradermal and compound naevi is not reliable. We appreciate that these discrepancies are of little importance in managing patients, but nevertheless they would affect epidemiological studies based entirely on clinical assessment. Of greater importance is the ability (or inability) to recognise dysplastic naevi. Only 20 (51\%) out of 39 dysplastic naevi were identified correctly by all observers, whereas 24 banal lesions were thought to be dysplastic on clinical grounds.

Studies have also shown poor agreement among histopathologists in diagnosing pigmented lesions. ${ }^{24}$ We took the opinion of one histopathologist with a particular interest in, and wide experience of, pigmented lesions rather than take the consensus view of several pathologists because we were concerned with the clinical and not the pathological validity of evaluating pigmented lesions.

In their study of melanocytic naevi in relation to phenotype $^{25}$ and their site specific naevus counts ${ }^{26}$ English et al counted pigmented lesions of greater than $2 \mathrm{~mm}$ that were not obviously lentigines, seborrhoeic keratoses, or freckles. Rampen and colleagues counted all clinically apparent moles, the smallest of which were about $1 \mathrm{~mm}$ across. ${ }^{27} 28$ The contrasting results of English et al and Rampen and colleagues of the relation between phenotype and banal melanocytic naevi possibly related to a difference in the nature of the lesions being counted; in the present study we found it difficult to diagnose small $(<5 \mathrm{~mm})$ flat lesions of any type accurately. Our results suggest that critical diagnosis and management decisions concerning pigmented lesions should always be based on a combination of clinical and histopathological assessments and an assessment of the history of the patient.

1 Swerdlow AJ, English J, MacKie RM, et al. Benign melanocytic naevi as a risk factor for malignant melanoma. Br Med f 1986;292:1555-9.

2 Green A, MacLennan R, Siskind V. Common acquired naevi and the risk of malignant melanoma. Int $\mathcal{F}$ Cancer 1985;35:297-300.

3 Elder DE, Goldman LI, Goldman SC, Greene MH, Ckark WH Jr. Dysplastic nevus syndrome: a phenotypic association of sporadic cutaneous melanoma. Cancer 1980;46:1787-94

4 Milne JA. An introduction to diagnostic histopathology of the skin. 2nd ed. London: Edward Arnold, 1972:291-316.

5 Pinkus H, Mehregan AN. A guide to dermatopathology. 3rd ed. Norwalk: Appleton Century Crofts, 1981:351-81.

6 Lever WF, Shaumberg-Lever G. Histopathology of the skin. 6th ed. Philadelphia: Lippincott, 1983:681-725.

7 Clark WH, Elder DE, Guerry D, Epstein MN, Greene MH, Van Horn M. A study of tumour progression. The precursor lesions of superficial spreading and nodular melanoma. Hum Pathol 1984;15:1147-65.

8 Cook MG, Robertson I. Melanocytic dysplasia and melanoma. Histopathology 1985;9:647-58.

9 Becker SW. Pitfalls in the diagnosis and management of melanoma. Archives of Dermatology and Syphilology 1954;69:11-30.

10 McMullan FH, Hubener LF. Malignant melanoma: a statistical review of clinical and histological diagnoses. Arch Dermatol 1956;74:618-9.

11 Swerdlow M. Nevi: a problem of misdiagnosis. Am $\mathcal{J}$ Clin Pathol 1952;22 1054-60.

12 Rampen FHJ, Rumke P. Referral pattern and accuracy of clinical diagnosis of cutaneous melanoma. Acta Derm Venereol (Stockh) 1988;68:61-4.

13 Kopf AW, Minzis M, Bart RS. Diagnostic accuracy in malignant melanoma. Arch Dermatol 1975;111:1291-2.

14 Wagner RF, Wagner D, Tomich JM, Wagner KD, Grande DJ. Diagnosis of skin disease: dermatologists vs non dermatologists. $\mathcal{F}$ Dermatol Surg Oncol 1985;11:476-9.

15 Cassileth BR, Clark WH, Lusk EJ, Frederick BE, Thompson CJ, Walch WP How well do physicians recognise melanoma and other problem lesions? f Am Acad Dermatol 1986;14:555-60.

16 Ramsey DL, Fox AB. The ability of primary care physicians to recognise the common dermatoses. Arch Dermatol 1981;117:620-2.

17 Griffiths RW, Briggs JC, Hiles RW. Clinical diagnostic accuracy in the management of primary stage 1 cutaneous malignant melanoma in a plastic surgery unit. Bristol Medico-Chirurgical fournal 1984;99:55-60.

18 Becker SW. Diagnosis and treatment of pigmented naevi: considerations of some of the pitfalls. Archives of Dermatology and Syphilology 1949;60:44-65.

19 Ewing MR, Powell T. Some observations on the diagnosis of clinically pigmented skin tumours. Br f Surg 1951;38:442-54.

$20 \mathrm{Grob} \mathrm{JJ}$, Andrac L, Romano MH, et al. Dysplastic naevus in non-familial melanoma. A clinicopathological study of 101 cases. Br $\mathcal{f}$ Dermatol 1988;118:745-52.

21 Greene MH, Clark WH, Tucker MA, et al. Acquired precursors of cutaneous malignant melanoma: the familial dysplastic nevus syndrome. $N$ Engl f Med $1985 \cdot 312 \cdot 91-7$

22 Rigel DS, Friedman RJ. The management of patients with dysplastic and cogenital nevi. Dermatol Clin 1985;3:251-5.

23 Holly EA, Kelly JW, Shpall SN, Shu-Hui C. Number of melanocytic nevi as a major risk factor for malignant melanoma. I Am Acad Dermatol 1987;17: 459-68.

24 Schmoeckel C. How consistent are dermatopathologists in reading early malignant melanoma and lesions "pre-cursor" to them? Am $\mathcal{f}$ Dermatopatho 1984;6 (suppl):13-24.

25 English JSC, Swerdlow AJ, MacKie RM, et al. Relation between phenotype and banal melanocytic naevi. $\mathrm{Br}$ Med $\mathcal{F}$ 1987;294:152-4.

26 English JSC, Swerdlow AJ, MacKie RM, et al. Site-specific melanocytic naevus counts as predictors of whole body naevi. $\mathrm{Br} \mathcal{F}$ Dermatol 1988;118: 641-4.

27 Rampen FH, Fleuren BAM. Relation between phenotype and banal melanocytic naevi. Br Med f 1987;294:773.

28 Rampen FHJ, van der Meeren HLM, Boezeman JBM. Frequency of moles as a key to melanoma incidence? $\mathcal{J}$ Am Acad Dermatol 1986;15:1200-3.

(Accepted 10 April 1989)

\section{ONE HUNDRED YEARS AGO}

We have often commented on this public need of London, and are glad that the daily press is echoing the cry. The foreigner within our gates, says a daily contemporary, must surely wonder at the spectacle presented by the seatless London streets, when he is himself accustomed to cities where commodious restingplaces are to be found at every turn. The mere amount of physical suffering which elderly and feeble persons, and children, must endure from this easily-preventable cause it is difficult to estimate. It is, therefore, very much to be hoped that in course of time the Sewers Commissioners, or the authority which administers such matters for London generally, will see their way to give us seats here and there along our 3,000 miles of thoroughfare. Tree-planting and the provision of artificial brooks may come a little later on; at present it is difficult to understand why a public authority, when it has the offer of seats for its citizens "free, gratis, and for nothing," should decline the proffered boon. (British Medical fournal 1889;ii:85) 